\title{
Redefining Refugee Camps as Livable Cities (Case Study: Saveh Refugee Camp)
}

\author{
Diba Rashidi*, Seyed Behshid Hosseini \\ Faculty of Architecture and Urbanism, University of Art, Tehran, Iran \\ *Corresponding author: diba.rashidi@yahoo.com
}

\begin{abstract}
Every year, a large number of the Earth inhabitants have to leave their homeland due to violence and discrimination so that there are now over 60 million displaced people worldwide. Almost 20 million of them are refugees. In this circumstance, refugee camps, considered a common settling way, not only have a great effect on the current lives of refugees, but also influence their future lives because of the long-term presence of refugees in such an environment. The purpose of this study is to review the refugee camps from economic, social, physical, managerial, and environmental perspectives. In the next step, the rational basis of refugee camps as a city is explained by examining city, its features, and its dimensions and comparison with refugee camps. Afterward, diverse criteria are developed to improve the quality of life in various social, environmental and physical dimensions using the livability approach. These criteria are the basis of redesigning Saveh Camp, Iran as a livable city. Finally, a livable city-based design is proposed for the case study.
\end{abstract}

Keywords: refugees, camp, livability, quality of life, livable city

Cite This Article: Diba Rashidi, and Seyed Behshid Hosseini, "Redefining Refugee Camps as Livable Cities (Case Study: Saveh Refugee Camp)." American Journal of Civil Engineering and Architecture, vol. 6, no. 1 (2018): 1-12. doi: 10.12691/ajcea-6-1-1.

\section{Introduction}

The continuation of conflicts, persecution, organized violence and human rights violations have led to the people's displacement in different parts of the world during the first half of 2015. Yet, 59.5 million people had become homeless by the end of 2014 as a result of war and violence, of which 19.5 million were called refugees according to the international definitions. According to the UN statistics, at least 5 million people were added to the homeless over the first half of 2015 [1]. Accordingly, there are now more than 65 million displaced people around the world that can exceed the population of a country.

Until July 2015, 169 countries had accepted refugees in their homeland among which Iran ranked fourth in terms of refugees entering its territory prior to the new crisis of refugees after Turkey, Pakistan, and Lebanon [1]. Most of refugees living in Iran are from Afghanistan $(950,000)$ followed by Iraqis $(32,000)$. This population is mostly living in rural and urban areas. Only 3\% are residing in refugee camps. Until 2014, repatriation efforts had been made; however, the trend has stopped due to the regional crisis [2].

After a war, as stated by Boyman in his studies, what remain are damaged citizens and ruined buildings. In such circumstances, the restoration of city and repatraiation require a master plan design. The plan includes the selection of residential place for the battle-scarred citizens, the supply of basic needs, grant of facilities, and restoration of the citizens to country's economic cycle. Architecture plays a key role in providing this master plan, which is a physical response to the needs of these people. The design and construction of war refugee camps play a vital role in architecture in this context. In order to understand the effect of architecture effectiveness, the general approaches to dealing with refugee settlementscity and/or camp- need to be examined [3].

Refugee camps can be described as a place between formalities and non-formalities, dynamics and stagnation, survival and destruction, and in general, a paradoxical place. On the one hand, camps can be understood as an exceptional range on the community's periphery that is limited, controlled and filtered from the outside. On the other hand, camps can be the space within which the identity is formed, individuals' empowerment is encouraged, and resistance is practiced [4]. In the process of defining this dichotomy, two terms conflict each other: "Camp" as a special lifestyle and in exceptional circumstances and "City" as the normal lifestyle [5]. With the consideration of purposes and the interactions among the elements, dealing with refugee camps as a city has remained in the theoretical field; however, there are many traditional camps around the world some of which are as follows. Extensive studies have been conducted in relation to refugee camps. For instance, the study by Zeus discovered the obstacles to access to education for teens and young people in the camp [6]. Another study by Wilson examined the food supply in refugee camps. The allocation and physical location for food production and distribution show the role of architecture in designing refugee camps [7]. Werker examined the economy of 
camps. In his study, he emphasized the economic independence of refugee camps. In this study, providing appropriate physical space along with training and the creation of job opportunities for those residing in camps is introduced as the most fundamental basis [8]. According to aforementioned issues, it is necessary to design and develop the principles of constructing camps, so that the basic needs are met and it facilitates the repatriation of war-torn citizens to normal life cycle.

According to the statistics and studies, it is certain that despite the efforts made by the UN, governments, and NGOs for turning these camps into livable ones, their conditions are something between intolerable and catastrophic. Some of these camps do not even have the basic needs such as drinking water, restrooms, medical facilities, and even enough food. Diseases are prevalent, children have no access to education, and they sometimes live under the threat of being driven out of these camps [9]. Accordingly, the very first and the most important purpose of defining camps is to try to increase the quality of life and make camps livable places [10].

There is no clear definition of the quality of life [11] so that the quality of life is a multidimensional concept with distinct ones for various individuals. Some believe that the quality of life is the livability of region, while others say that it is an indicator to measure the extent of attractiveness. Some other people believe that it is the general welfare, social well-being, happiness, satisfaction, etc [12].

Livability is a general concept related to other terms and concepts such as stability, quality of life, quality of place, and healthy communities so that it is divided into three interdependent spheres: economy, society, and environment [13]. The disruption of any of these sections leads to the settlement collapse [14]. Depending on the context, livability can be vast or limited. Yet, the quality of life in each place is the center of attention, which included various criteria: density, transportation, security and sustainability. Despite the factors leading to the displacement of over 65 million people until the mid-2015, a wide range of programs have been developed to address the necessity of selecting location for war-torn citizens, the supply of basic needs, facility granting, and return of these individuals to the economic cycle. In the common approach to refugee camps and understanding them as exceptional space around cities, shortcomings are observable including lack of access to education, the barriers to food supply, the economic dependence of individuals, etc. Accordingly, as second approach was developed to deal with camps as cities and understand their needs as a city. In the process of developing camps towards cities, the extent of camp urbanization needs to be assessed by considering the methods by which camps receive a multidimensional identity and passes the borders of cities and non-cities. What we mean by city and urbanization is not only the physical body but a place for specific formation of political communities and even a community to illustrate the rights of citizens [4]. On the other hand, efforts have always been made to change the camps into livable places but with minimum facilities. This leads to the necessity of examining theses spaces as livable city. In this article, camps are taken into account as a livable city in order to supply the physical needs such as food and shelter and consider the psychological needs such as security, sense of attachment, etc. as citizens

\section{Literature Review}

Refugee camps are not a contemporary phenomenon. One of the first examples of refugee camps is mentioned in Gospel and in Exodus, which deals with the escape of the Jewish people from Egypt. Throughout the history of mankind, there have always been examples of conflicting thoughts that have led to the persecution of some individuals, be driven from their land and eventually led to the displacement. However, the development of camp was mostly influenced by the conflicts in the modern world. After the World War I, many people were displaced; however, the formation of refugee camps in its modern meaning dates backs to the aftermath of the World War II. Until the end of the Cold War, this way of dealing with refugees expanded [9]. Civil wars, intensified since the end of colonialism, led to a revolution in expanding refugee camps in the modern era. The end of the Cold War also revived old hostilities and increased emergency situations by tension, increased the number of people affected by such tensions, changed the nature of refugees, and expanded the numbers of camps [15].

In line with the literature review on the design of refugee camps, we can point the Bangladeshi urban war refugee camp in 1971. During the invasion of India in eastern Pakistan in December 1971, almost 10 to 12 million Bengali fled to India to escape the damage of war. Most of this population was settled in camps near the border. Most of these camps were located the West Bengal state, especially near Kolkata. The size of camps varied from a minimum of 3,000 to 250,000 inhabitants. Three types of settlement were identified to construct the camp based on different stages of the crisis and planning. Firsttype camps were those set up at the beginning of the arrival of war victims. Therefore, there was no settlement planning as a result of lack of time. The Indian government considered the situation temporary and only provided the essential needs including water, food, blanket. Since these camps were temporary, they were located near the railways, urban highways, and airports. According to its temporary conditions, and with the increase in population, first-type camps had the worst living conditions among three types of camps. Second-type camps were somewhat planned. Unlike the first-type camps, there was no time set for shutting them down. Second-type camps, in fact, had better physical conditions than the first type. However, the difference between the second type and first type lies in stronger and more stable structures provided by the government and aid agencies such as the Red Cross. In these camps, field hospitals were also another distinguishing factor. Third-type camps, built with a long-term perspective, were designed in such a way to make their control, management and events inside maximally possible. Due to the predetermined plan, not only the construction costs were drastically reduced, but also it was possible to address the inhabitants' basic needs. The superiority of third-type camps was to have a master plan for the development of refugee camps prior to being settled. The key parameter for the success of third- 
type camps was the consideration of the design conditions, not as temporary accommodation, but as a permanent residence, which, in addition to meeting the basic and urgent needs of the residents, paid attention to their needs at higher levels. Certain measures such as how to supply food, access to water and build strong shelter before the arrival of refugees to the sites were key success points in third-type camps [16].

Another initial experience of refugee camp was design of a camp for December 1972 Earthquake victims in Managua, Nicaragua. Although international agencies and voluntary assistance quickly entered the damaged areas, the central government's lack of readiness to deal with such incidents made the settlement difficult so that no decision was made on how to resettle the victims two weeks after the earthquake. As a result of this confusion, some victims joined their relatives in other cities. A massive number of the displaced were transferred to squares, parks, and lots around the cities. Finally, on January $6^{\text {th }}, 1973$, the central government announced that it would set up a set of camp for those who were not able to join to their relatives in other cities. The plan used to construct these camps was cross-shaped, with small communities of 10 to 16 households around a central building (management core) with departments such as clinics, equipment and installations, and food and water distribution management. In designing each small community, in addition to considering a private space around the shelter of each household, public spaces were open for public meetings. In these areas, the inhabitants were provided with essential training and information by the management core $[17,18]$.

In relation to the experience in Chad, Herz wrote that Ambuko was the first camp for refugees from Central Africa. In April 2003, UNHCR rapidly made this camp on the basis of United Nations Guidelines as a mud huts in a pre-forestry area. The residential area is located along the main path, reaching the central market. In this market, refugees sell various goods including agricultural products, grown in small vases, goods taken from their homes, or clothes or sew clothes by sewing machines provided by NGOs. Certain services such as clinics and schools are next to the market. Sanitary facilities and drinking water taps are provided proper distances. In expansion stage, the population density has remained steady. It still has no proper access to roads [15].

UNHCR used a hybrid strategy for constructing the second camp, Gaga. It means that main services such as clinics and schools need to be jointly used. However, in practice, it led to the permanent residence of these people in Chad. Yet, the priority of international community and UN is always $t$ bring these people back to their homes. Only when it is assured that there is no possibility of returning for a long time, permanent settlement in another country is a solution. On the other hand, the joint use of hospitals and schools enabled the use of these services for local residents of Chad. Emergency services and assistance, considered for refugees to save their lives, became a part of the Chad development program. An adverse effect of this issue is lack of Chad government commitment to meet the needs of its own people. Therefore, they heavily rely on NGO's and international community's assistance.
In the planning phase, the integration strategy means more space. It means that $200 \mathrm{~m}^{2}$ was allocated to households instead of $45 \mathrm{~m}^{2}$ per capita. In this camp, the refugees were asked to plant vegetables in line with self-sufficient policy. This issue, which is considered technically positive, led to serious demographic consequences. Some rural refugees easily adapted to the program; however, other nomads were not interested in planting veritable nor did not use vegetable much in their meals. The latter group was not cooperative. However, these two groups of farmers and ranchers were mixed and created a relatively self-sufficient village community. In this project, architecture and camp planning fundamentally changed to demographic structure of the region.

Each of these two camps has over 15,000 inhabitants, and has gradually become permanent settlements. They are larger than most of Chad cities. Despite their vast size, their structure is not based on the structure of a city. They are very large and there are no gathering centers due to very low population density. Their various areas do not have specific characteristics. These camps look like suburban residential areas due to low population density. The difference lies in the fact that they do not supply ant big cities.

The world's current camps can be examined in three following areas:

1. Table 1 campares the camps in terms of construction patterns and facilities. The results and consequences have been fully explained.

2. Three patterns can be seen in examining camps (temporary, semi-temporary, and permanent). The design and level of refugees' needs are of great importance due to the long-term presence of individuals in these camps. Semi-temporary camps are the subject of the study due to the global crisis of displaced people, which eliminates the possibility of their short-term return and international community desire for the return of refugees to their own country.

3. The camps constructed in cities can be compared. Despite accommodating people and having areas greater than the host countries, some of these camps are not similar to cities, which has caused certain problems. Although the camp design has been taken into account by experts, a constructed camp does not exist.

According to the aforementioned issues, the most important failures of current camps and studies in this regard are different. First, lack of coherent planning is the most important factor of failure. On the other hand, comprehensive and correct proper per capita and standards have not been developed in terms of responding to physical and material needs. As a result, basic needs such as rest rooms have not been accessible in some cases. Another failure of previous studies is lack of attention to psychological needs of camp residents as affected individuals with their certain needs. Some issues such as sense of attachment and security have completely been ignored, leading to certain consequences. Camp's economy and economic self-sufficiency are other important factors with no comprehensive and diverse solutions. Finally, current tents, provided by the UN, last, on average, only 6 
months; however, every family lives for almost seven years in camps. Therefore, these tents need to be frequently changed. No comprehensive study has been conducted in terms of tent replacement. The livability approach has helped the promotion of quality of life in cities. Taking advantage of livability in refugee camp design is likely to help the better quality of life. But, what is livability and what are its elements?

Table 1. Construction pattern and facilities of some camps, Source: Author

\begin{tabular}{|c|c|c|c|}
\hline Year & Geographical Location & Construction-related issues & Facilities \\
\hline 1971 & India & $\begin{array}{l}\text { An unplanned camp was constructed near } \\
\text { railways, urban highways, etc. }\end{array}$ & Basic needs (water, food, blanket, and basic supplies) \\
\hline 1971 & India & & Field hospital with basic needs. \\
\hline 1971 & India & $\begin{array}{l}\text { A planned camp and master plan for future } \\
\text { development }\end{array}$ & $\begin{array}{l}\text { In addition to basic needs, higher-level needs were also } \\
\text { taken into account. }\end{array}$ \\
\hline 1973 & Nicaragua & A cross-shaped plan with central core & $\begin{array}{l}\text { Clinics, water and food distribution equipment, private } \\
\text { space around the household shelter, public gathering } \\
\text { area }\end{array}$ \\
\hline 2003 & Chad & Mud huts along a main road and the core & $\begin{array}{l}\text { In addition to basic needs, clinic, and school, market } \\
\text { was anticipated for selling the products of refugees. } \\
\text { Future development plan was also considered. }\end{array}$ \\
\hline
\end{tabular}

Table 2. Livability Components Commented by ExpertS

\begin{tabular}{|c|c|c|}
\hline Theorist & Field & Livability components \\
\hline Donald Appleyard [20] & Livable streets & $\begin{array}{l}\text { - A historical place } \\
\text { - Green space } \\
\text { - Playground } \\
\text { - Neighborhood } \\
\text { - Community } \\
\text { - A healthy environment } \\
\text { - Privacy }\end{array}$ \\
\hline $\begin{array}{l}\text { Susan and Henry Lennard } \\
\text { [21] }\end{array}$ & Livable city (Social principles) & $\begin{array}{l}\text { - Easy and safe access to urban spaces } \\
\text { - The possibility of frequent and regular use from space } \\
\text { - Feeling important and respecting the self-esteem } \\
\text { - Strengthening the sense of attachment } \\
\text { - Facilitating various activities and directing public activities } \\
\text { - Sense of being at home for different people }\end{array}$ \\
\hline $\begin{array}{l}\text { Susan and Henry Lennard } \\
\text { [21] }\end{array}$ & Livable city (Design principles) & $\begin{array}{l}\text { - Walking access to urban spaces } \\
\text { - Social life in space } \\
\text { - Sense of attachment and visual centrality } \\
\text { - Proper design of sitting areas } \\
\text { - Visual and face-to-face eye contact }\end{array}$ \\
\hline $\begin{array}{l}\text { Susan and Henry Lennard } \\
\text { [22] }\end{array}$ & Principles for a livable city & $\begin{array}{l}\text { - Conversation is important } \\
\text { - The role of public territory } \\
\text { - A place for social learning } \\
\text { - The fulfillment of socio-cultural-economic functions } \\
\text { - Mutual value and recognition } \\
\text { - The priority of beauty and meaning of physical environment }\end{array}$ \\
\hline $\begin{array}{l}\text { Partners for Livable Cities } \\
\text { [24] }\end{array}$ & Livable city & $\begin{array}{l}\text { - Safe neighborhoods } \\
\text { - Safe economic network } \\
\text { - Settlement in city center } \\
\text { - City enter revival } \\
\text { - New community leadership } \\
\text { - Financial participation }\end{array}$ \\
\hline Peter Evans [25] & Livable cities & $\begin{array}{l}\text { - Local communities and NGOs } \\
\text { - Companies } \\
\text { - The existence of civil society }\end{array}$ \\
\hline Emily Buchwald [26] & Towards livable cities & $\begin{array}{l}\text { - Paying attention to pedestrian movement } \\
\text { - The arrival of nature to the city } \\
\text { - Food production within the city } \\
\text { - Proper mixing of applications } \\
\text { - Restoration of beaches for recreation } \\
\text { - Creating efficient urban infrastructure } \\
\text { - Housing in right places } \\
\text { - Observing modernization charter }\end{array}$ \\
\hline Elliott [27] & $\begin{array}{l}\text { A better way to zone: ten } \\
\text { principles to create more } \\
\text { livable cities }\end{array}$ & $\begin{array}{l}\text { - Paying attention to pedestrian movement } \\
\text { - The arrival of nature to the city } \\
\text { - Food production within the city } \\
\text { - Proper mixing of applications } \\
\text { - Creating efficient urban infrastructure } \\
\text { - Housing in right places }\end{array}$ \\
\hline
\end{tabular}


The study, entitled Towards Livable Cities, in Shanghai defines livable city as follows: "A livable city is the one that provides high quality of life for its citizens." Strong economy, social balance, and continuity of ecological life (a sustainable environment) are required to create a livable city. According to these reports, certain factors prepare the ground for the realization of quality of vitality including infrastructures, access, quality of architecture, urban design, public transportation, public places, security and crime, educational facilities, reconstruction, political stability, the accessibility of goods and services, and socioeconomic conditions [19].

As a city providing all facilities for its residents, a livable city has the following features:

\section{Strong economy}

2. Social equalities

3. Environmental livability

All these factors are interrelated in livable cities.

Livable city is a bridge between the past and the future. Livable city, on the one hand, respects historical symbols, and, on the other hand, honors what is not born (future). According to the experts, a livable city different features, which are mentioned in Table 2:

\section{Case Study}

With an area of over $446 \mathrm{~km}^{2}$ and population of over 23,000, Saveh is considered the largest city of Markazi Province, Iran [28]. It borders with Qazvin to North, Tafresh and Qom Province to South, Tehran and Karaj to North and Northwest, and Hamedan to West [29]. Saveh is located at height of 1050 meters. The Qara-Chai River originates from the Tafresh Mountains and flows to the Qom Lake after feeding the south lands of Saveh. The region has a mild and semi-arid climate with hot summer and a little cold winter. Saveh does not have a uniform social composition: Different ethnic groups are living in this industrial city. The intense emigration in recent years has shaken the city's social and ethnic composition and has accelerated over time [30].

With the population of 4987, Saveh Camp is located to the East of Saveh in Taraz Nahid Road. The camp was established 32 years ago. Five ethnic Afghan groups are residing in the camp. $80 \%$ are Sunni and the rest are Shiite. Camp residents are mainly relatives, living together [30].

Until the early 2000s, the cost of the camp was fully paid by the Iranian government and relief agencies; however, from then onward, the refugees themselves were responsible for public service payment such as water, electricity, street, etc. in order to reduce the costs, help Afghan's self-sufficiency, and encourage repatriating. As a result, per capita aid policy was created. This per capita depends on the income at various camps. The main sources of revenue in camps are renting land, machineries, shops, etc. Some of these items belong to the Islamic Republic of Iran and some others belong to relief agencies such as the UN. Per capita was 464,000 IRR in Saveh Camp in 2017 [30].

Iranian camp management is on the basis of urban and rural council in Iran. Self-governing councils are formed from the camp residents. Depending on the camp population, the council can consist of 3, 5, or 7 members.
The council is responsible for controlling the budget, costs, and income. Camp manager is appointed by the government. He is responsible for monitoring the council performance for spending the budget in line with the public interests. Camp manager and others who work under his supervision are state employees; however, the salary of council members is paid from the camp revenues. Iranian camp managers hold an annual conference and try to share their experiences and comments in order to improve the quality of refugee lives [31].

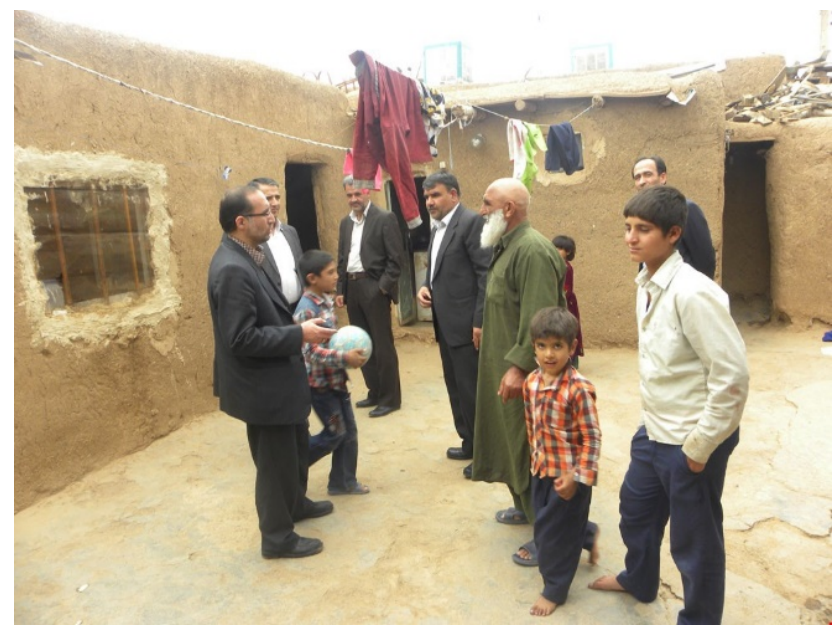

Figure 1. A Regular House In Saveh Camp

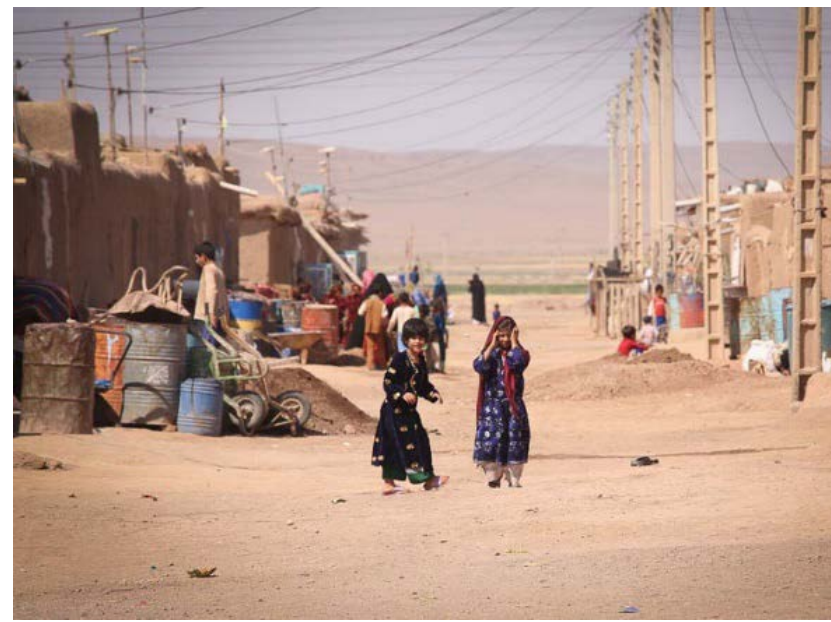

Figure 2. Saveh Camp Environment

One house, which can be seen in Figure 1 and Figure 2, is considered for every household in Saveh Camp. The camp was first established by some tents next to each other. Having accepted that these people would not repatriate to their home country soon, homes were made for them. These are one-floor houses, first made up of mud bricks. Gradually, families changes houses by other constructional materials [30].

This camp has two male and female schools (until the end of junior high school). Students have to go to Saveh for high school and university studies. Commuting buses have been provided for these students. Extracurricular activities are available in an active cultural center and library in the camp. These training are related to social harms, life skills, and religious issues. A public health center and a clinic are active in this camp. For serious diseases and surgeries, ambulances are used to transfer the 
patients to hospitals in Saveh. In addition to bathrooms at homes, there are 8 public bathrooms in the camp [30]. The infrastructures are drinking water system and exclusive water desalination devices, incomplete sewage system, garbage trucks, and lighting systems [31]. In general, international standards have been observed in the camps and they are above the average compared to the world camps. There are two playgrounds for kids and 7 mosques, out of which 6 belong to Sunni and one to Shiite population. Note that no mosque has been constructed for refugees by agencies. The refugees themselves have constructed these mosques [30]. The refugees are involved with various jobs in factories, and few are working in agricultural farms in Saveh. Some of these refugees have rented farms. Few make living as shopkeepers [30]. In general, employment rate is said to be very good compared to the world averages. Vocational training has been provided by the Iranian Ministry of Labor; however, most of the workforce acquired skills through apprentice [30]. The cost is reported almost 6 billion IRR in 2016, provided by the Iranian government or the camp revenue). The money was allocated for equipping water wells, chlorination system, asphalt, street patching, repair of shelters, and the establishment of dispute settlement committee. International organizations have also been active in surface water disposal, school and shelter construction, drug delivery, technology issues, and literacy and skill training [30]. As it is shown in Figure 3, the most important problem in the camp is the formation of organic urban structure that seriously impedes the creation of a sewage system and efficient surface water collection. This places the camp into an uncontrolled fire risk. It also prevents the commuting of emergency vehicles such as ambulances [10].

Figure 4, by examining the building orientation, shows three forms of spatial organization. Concerning the first form of houses, a number of houses are located around each other, providing negative, semi-private space. This structure, frequently repeated in the world's self-evoked camps, shows the effect of social structures on the physical structures. In terms of the second form, houses are built in along the roads and in a row. However, it is uncertain whether roads existed and then houses were built or vice versa. A mixture of the first and second form of houses is seen in some places. Finally, third-types house are those isolated and individually created in different places.

An important point is that there are scattered green spaces in the camp, showing the extensive, small-scale agriculture to supply food for family. Such green spaces are obvious in Figure 5. Note that although, stated by Reza Lak, only 39 families are currently involved with agricultural jobs, other individuals grow vegetables and even fruit trees [30].

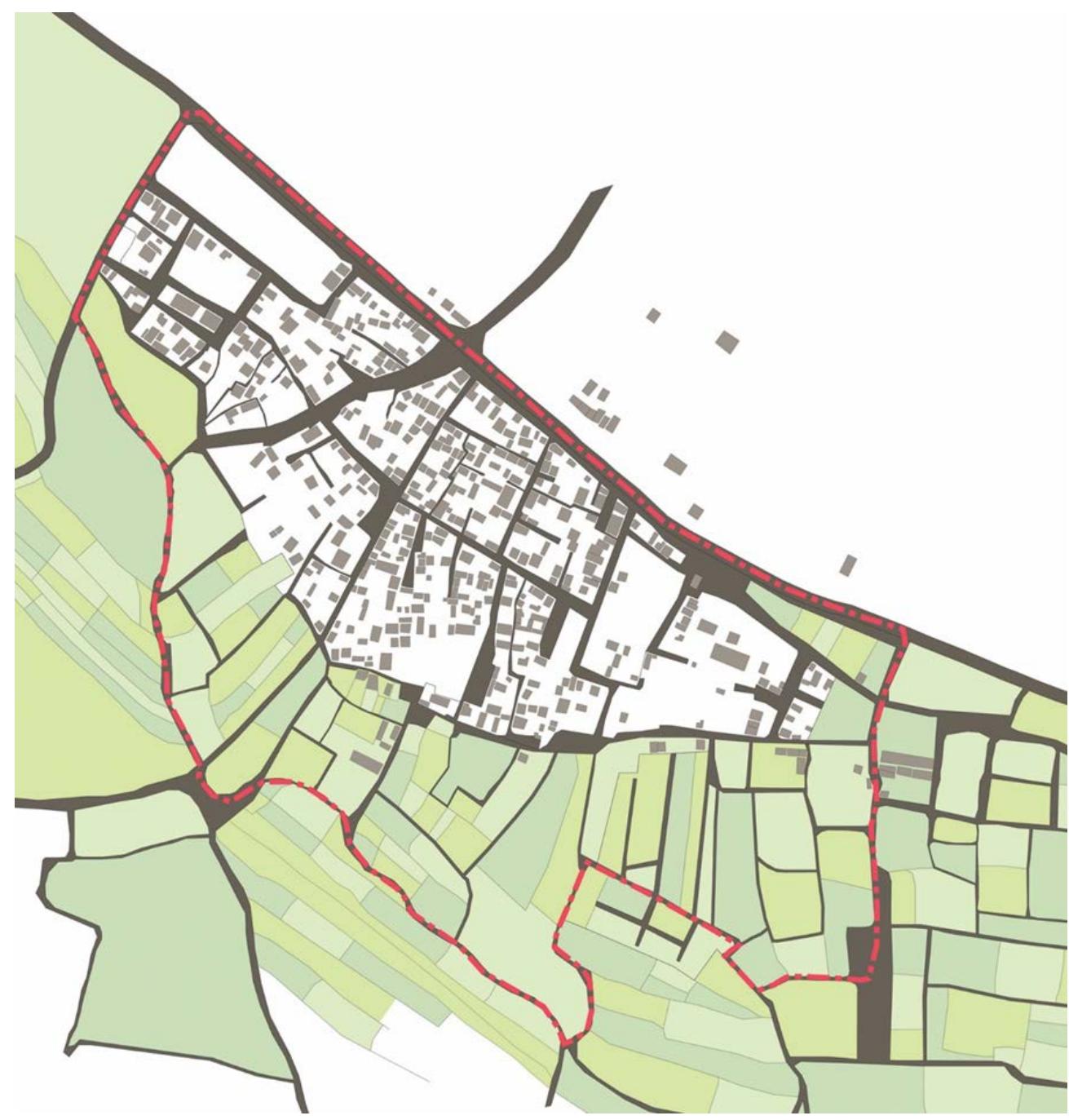

Figure 3. Saveh Camp Organic Urban Structure, Source: Author 

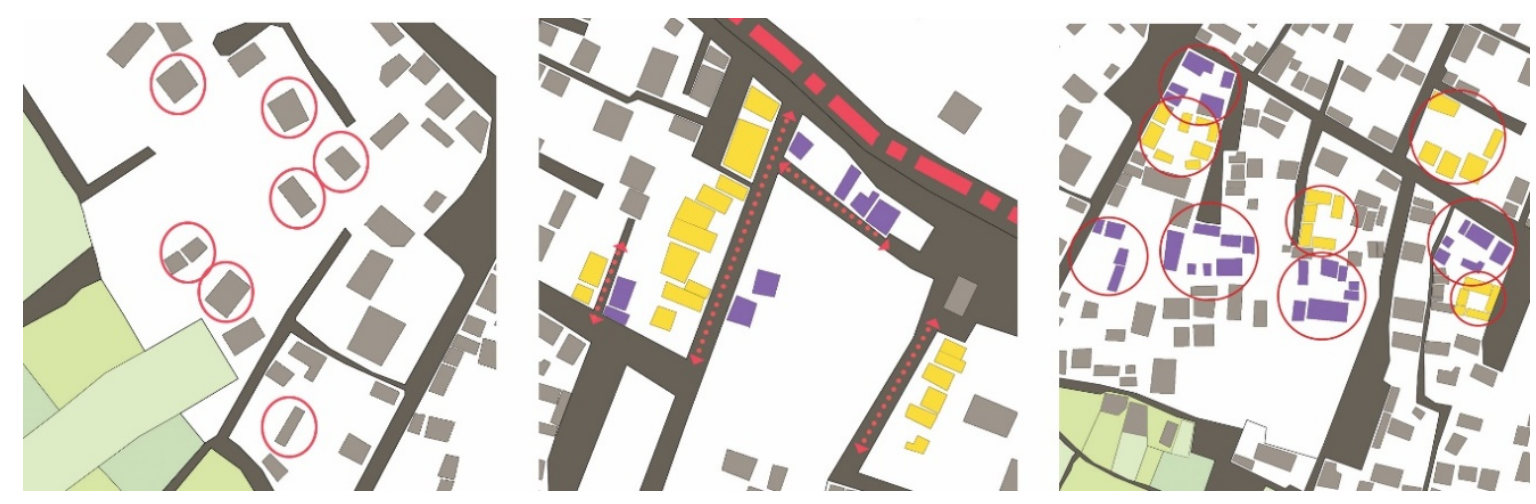

Figure 4. Three Types of Building Orientation and Physical Camp Structure, Source Author

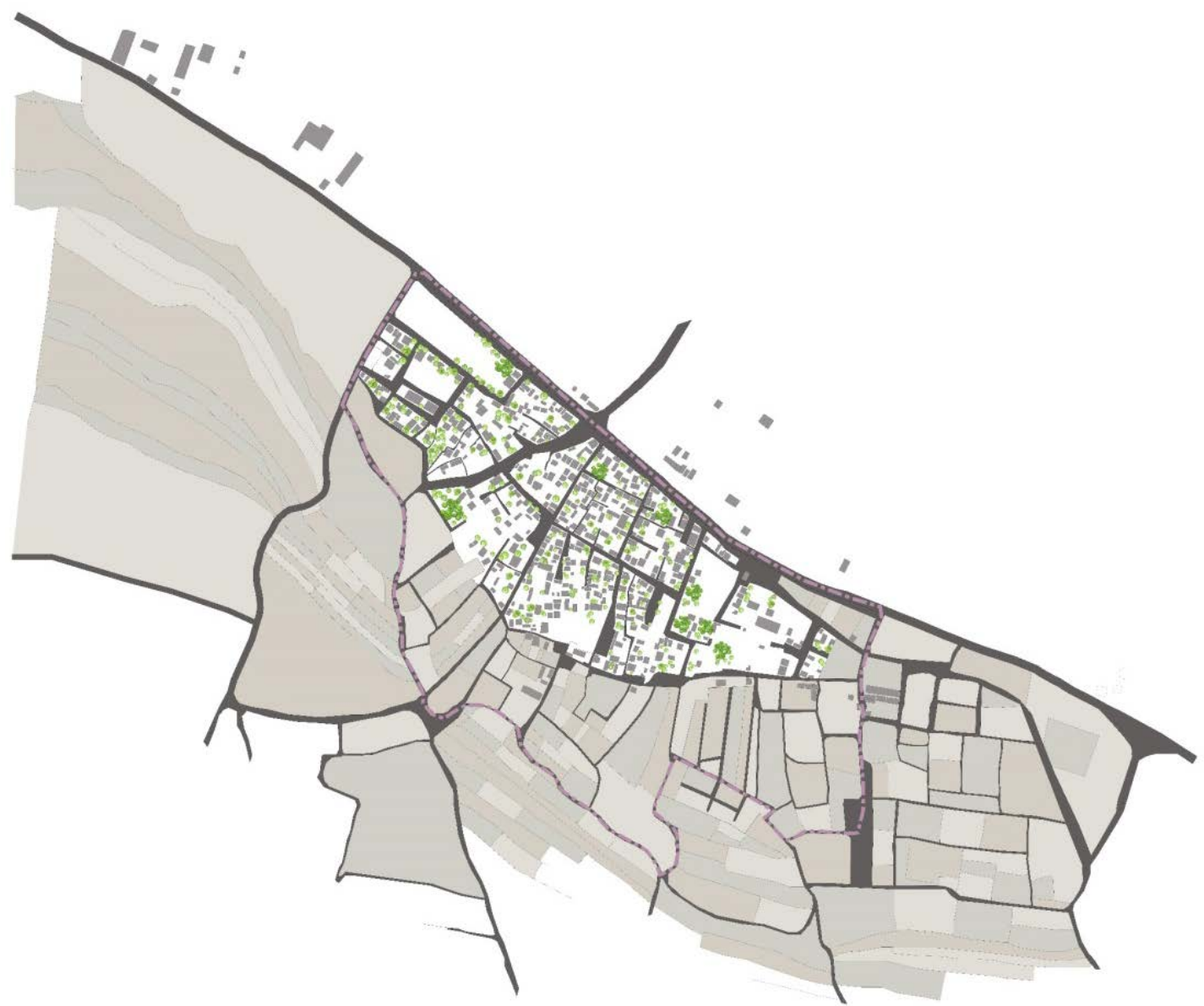

Figure 5. Green Space inside the Camp, Source Author

So far, Saveh and surrounding areas were examined as the context of the camp. Then the current camp was examined. Now, there is a comprehensive understanding of camp. According to the UN Handbook for Emergencies, designing refugee camp needs a component-whole approach to pay more attention to the social structure and residents' needs, so it is time to examine the proper technique for constructing a camp.

\section{Results}

In addition to cost effusiveness and easy and fast construction, other factors need to be taken into account for selecting an appropriate technique for constructing a camp. For example, according to the strict recommendation of UNHCR, refugees need to be hired. As a result, money is saved and refugees participate in constructing their own shelter and the sense of attachment is created. Possible space diversity needs to be taken into account while using a certain technique so that one of the livability principles is met. Another factor is the possibility of providing semiopen space, recommended by UNHCR as a solution for reducing dissatisfaction due to lack of per capita covered space. Various construction techniques are examined from different perspectives. First, traditional construction methods were considered. Using mud is common in rural region in order to build houses. In addition, there are newer methods to mix the mud with cement or nanomaterial, which could be used. The most important problem is short lifetime of mud structures and long construction process. However, the most obvious 
advantages are the use of residents for constructing, inexpensive materials, climate compatibility, and no damage to the environment.

In the next stage, construction methods in which the constructional materials are the waste or second-hand materials of other industries in the region are examined. This includes gabion walls where their raw materials can be the non-commercial parts in rock mines of surrounding Saveh. The abundance of rock resources near Saveh and Markazi Province provides inexpensive raw materials for the camp. Dry construction has the lowest environmental damage. Thick rock walls have very optimal performances in such a climate due to absorbing heat during the day and releasing it at night, providing the possibility of using refugees as workforce. However, this method is very slow. It occupies land due to the impossibility of constructing row buildings. Another point is construction by containers. The presence of active industries and factories in the region has provided a large number of containers. Lack of cost effectiveness of renting containers leads factories to buy the containers and sell them at the factory site. Therefore, there are always many containers next to the camp. Construction with these containers makes development possible in the future due to their modular nature. Their load capacity makes the construction of three-floor buildings possible and occupies less land. These containers are inexpensive, also providing the possibility of using refugee workforce. Since the components are recyclable and complex foundation is not required, little environmental damage is expected. However, the best response is not achieved in this climate: isolation is required. Crane is also needed during construction. These structures excluded in the process of examination due to the strong UN recommendation in terms of not using prefabricated structures; however, semi-prefabricated are taken into account. The first case is LSF, which is reasonable, providing flexibility for designing. They are environmentally-friendly due to little damage caused by recycling nature. It also makes the construction of row buildings possible, providing the simple construction of shelters over time. Although this method is very fast, semi-professional workforce is required. The second technique is prefabricated dome structures. In this method, concrete pieces are constructed in factories and connected in place. These are the fastest and most inexpensive semi-prefabricated structures. The concrete is very compatible with the regional climate. The damage is little over time, providing the possibility of optimal use of refugee workforce. However, it minimizes the diversity in camps, facing camp in terms of optimal and maximum use of little space.

For selecting the most appropriate technique, the best method is quantifying the comparison. To this end, the method proposed by Porter is used. Porter method evaluates internal and external factors in strategic management of organizations, known as Porter's 5 Forces Model. According to this technique, as shown in Table 3, first, factors affecting the construction method in factory are written in the first column. In the next column, a weight, ranging from zero to one, is assigned depending on the importance of factor so that the total sum of all factors is one. In the next column, a score, ranging from 1 to 4 , is assigned depending on the effectiveness of each factor in the quality of construction using the method. Finally, the total sum of techniques is compared. Note that. In ideal condition, the weight of each factor, which is the importance of factor, needs to be determined through interviews with the refugees. These extensive interviews show the real needs of refugees. Accordingly, the architectural solution to these needs is then proposed. The lack of cooperation of the Ministry of the Interior for visiting Saveh Camp led to detection of effective factors and their corresponding importance through Delphi by interviews with Ph.D. students of urbanization and architecture of Tarbiat Modaress University of Tehran, Iran.

According to Table 3, mud architecture is the best construction technique in Saveh Camp. Although mud was common in the past, the most important point in this study is that mud can be used in a modern way to achieve the best results.

Table 3 Finding the best construction technique with Porter's 5 Forces technique

\begin{tabular}{|c|c|c|c|c|c|c|c|c|c|c|}
\hline \multirow{2}{*}{ No. } & \multirow[b]{2}{*}{ Evaluation Factor } & \multirow[b]{2}{*}{ Weight } & Weight & $\begin{array}{l}\text { Weight } \\
\text { Score }\end{array}$ & Weight & $\begin{array}{l}\text { Weight } \\
\text { Score }\end{array}$ & Weight & $\begin{array}{l}\text { Weight } \\
\text { Score }\end{array}$ & Weight & $\begin{array}{l}\text { Weight } \\
\text { Score }\end{array}$ \\
\hline & & & \multicolumn{2}{|c|}{ LSF } & \multicolumn{2}{|c|}{ Container } & \multicolumn{2}{|c|}{ Mud Architecture } & \multicolumn{2}{|c|}{$\begin{array}{c}\text { Prefabricated Dome } \\
\text { Architecture }\end{array}$} \\
\hline 1 & Cost Effectiveness & 0.13 & 2 & 0.26 & 4 & 0.52 & 4 & 0.52 & 3 & 0.39 \\
\hline 2 & Easy Construction & 0.11 & 1 & 0.11 & 2 & 0.22 & 3 & 0.33 & 3 & 0.33 \\
\hline 3 & Fast Construction & 0.1 & 4 & 0.4 & 3 & 0.3 & 1 & 0.1 & 3 & 0.3 \\
\hline 4 & $\begin{array}{l}\text { Possibility of Using Refugee } \\
\text { Workforce }\end{array}$ & 0.09 & 2 & 0.18 & 2 & 0.18 & 4 & 0.36 & 1 & 0.09 \\
\hline 5 & $\begin{array}{l}\text { Possibility of supplying semi-open } \\
\text { space for every household }\end{array}$ & 0.07 & 3 & 0.21 & 2 & 0.14 & 3 & 0.21 & 1 & 0.07 \\
\hline 6 & Climatic compatibility & 0.11 & 2 & 0.22 & 1 & 0.11 & 4 & 0.44 & 3 & 0.33 \\
\hline 7 & No environmental damage & 0.06 & 2 & 0.12 & 3 & 0.18 & 4 & 0.24 & 2 & 0.12 \\
\hline 8 & $\begin{array}{c}\text { Possibility of constructing diverse } \\
\text { shelters }\end{array}$ & 0.06 & 4 & 0.24 & 2 & 0.12 & 2 & 0.12 & 2 & 0.12 \\
\hline 9 & $\begin{array}{l}\text { Less occupation rate compared to } \\
\text { more useful space }\end{array}$ & 0.08 & 4 & 0.32 & 4 & 0.32 & 2 & 0.16 & 1 & 0.08 \\
\hline 10 & Space Division Possibility & 0.06 & 3 & 0.18 & 3 & 0.18 & 2 & 0.12 & 1 & 0.06 \\
\hline 11 & Development Possibility over tine & 0.07 & 3 & 0.21 & 3 & 0.21 & 3 & 0.21 & 2 & 0.14 \\
\hline 12 & Resistance against erosion over time & 0.07 & 3 & 0.21 & 3 & 0.21 & 1 & 0.07 & 4 & 0.28 \\
\hline & Total & 1 & & 2.66 & & 2.69 & & 2.88 & & 2.31 \\
\hline
\end{tabular}


Table 4. Functions needed in Saveh Camp

\begin{tabular}{|c|c|c|}
\hline Functions & Description & Overall Area \\
\hline Shelter & & $56 \mathrm{~m}^{2} /$ family \\
\hline Children's Playground and Gardens & $1-3 \mathrm{~m}^{2}$ per person (minimum land area:650m²) & $5,000 \mathrm{~m}^{2}$ \\
\hline Commercial Space & $\begin{array}{l}\text { - One unit per } 255 \text { individuals } \\
\text { - Maximum land area: } 500 \mathrm{~m}^{2} \\
\text { - Vegetable and fruit stores, bakery, butchery, post } \\
\text { office, newsstand, barbershop } \\
\text { - It is better to locate them next to the distribution } \\
\text { centers and main paths. }\end{array}$ & Almost 2,000 $\mathrm{m}^{2}+$ one restaurant \\
\hline Primary School & $\begin{array}{l}\text { Minimum } 9 \mathrm{~m}^{2} / \text { person }\left(5 \mathrm{~m}^{2} \text { open space and } 4 \mathrm{~m}^{2}\right. \\
\text { covered space) }\end{array}$ & \multirow[t]{2}{*}{ A female and a male school (each $1700 \mathrm{~m}^{2}$ ) } \\
\hline Junior High School & Minimum $11 \mathrm{~m}^{2} /$ student & \\
\hline Athletic & Small playgrounds & \\
\hline Medical & Clinic & $650 \mathrm{~m}^{2}$ \\
\hline Religious & Mosque & $\begin{array}{l}\text { No religious spaces are constructed in camps. Refugees } \\
\text { themselves will construct them in the future. }\end{array}$ \\
\hline Urban Equipment & Garbage collection station & One \\
\hline Gardens and farms & Gardens, residential garden units, and farms & \\
\hline Water Tap & One tap/ 200 individuals & \\
\hline Rest Room & One restroom/family & \\
\hline Trash can & One trash can/ 10 families & \\
\hline Goods Distribution Center & One center/ 5,000 individuals & $200 \mathrm{~m}^{2}$ \\
\hline Cemetery & Eliminated due to the proximity of Saveh cemetery & \\
\hline Warehouse & $\begin{array}{l}\text { Watch room, open space warehouse, closed space } \\
\text { warehouse, delivery space }\end{array}$ & $5,000 \mathrm{~m}^{2}$ \\
\hline Administrative Spaces & $\begin{array}{l}\text { - Centrally located or near the entrance gate } \\
\text { - Management office, first registration space, and } \\
\text { some administration rooms }\end{array}$ & $800 \mathrm{~m}^{2}$ \\
\hline Bus and taxi stop & $\begin{array}{l}\text { For school and university commuter buses and mini } \\
\text { buses and public transportation to Saveh }\end{array}$ & \\
\hline Cultural Center & Community hall, class, and library & $350 \mathrm{~m}^{2}$ \\
\hline Workshop & Two industrial sheds for construction & $1600350 \mathrm{~m}^{2}$ \\
\hline
\end{tabular}

A modern architectural method is using Rammed Earth Architecture. This is a widely-used method in green architecture in recent years in Australia and the USA. This traditional construction method strengthens mud by adding cement and protects its various layers against humidity and erosion over time. According to the purpose of this study, UNHCR standards, and livability criteria, the following uses, visible in Table 4, are proposed. Although this table can be used for almost all world camps with slight changes, it is specifically prepared for Saveh Camp based on the needs and its potentials.

After deciding about construction technique and programming, a holistic design approach was needed to redesign the Saveh camp. In addition to 16 homes, known as community according to UN modules, a smaller module, made up of 4 homes, is created in order to provide the residents with more private space (Figure 8, Figure 11). Moreover, Figure 10 indicates that each neighborhood has a private garden which can be used to harvest some edible plants which is very pivotal to enhance the quality of nutrition of the households.

Instead the conventional emphasis on marginal expansion, camp expansion trend emphasizes the internal development so that each neighborhood has enough space for an extra shelter, which can gradually be used for the population growth needs (Figure 9). Therefore, central overcrowding and lack of access to marginal areas are prevented. In addition, each shelter has a planned development schedule, which can gradually be constructed by the residents themselves. Not only does camp construction cost reduce but also higher quality of life is gradually provided for the residents. More importantly, the residents are given enough incentives for making efforts. This gradual development is evident in Figure 6.

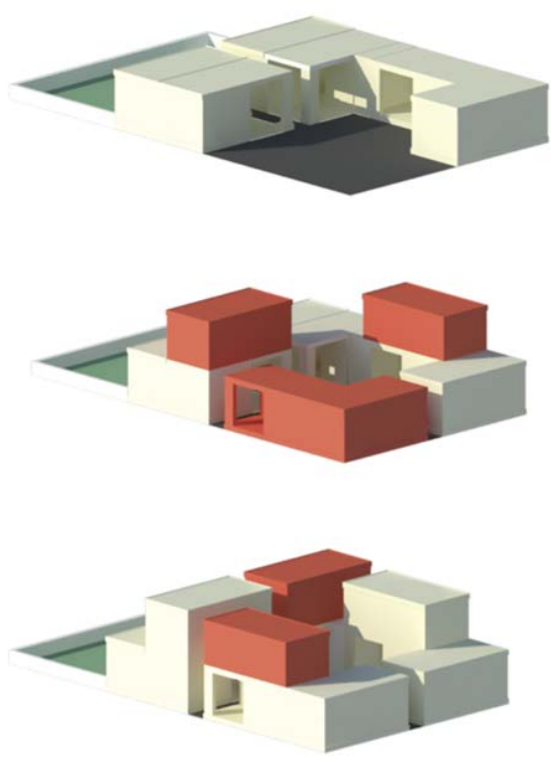

Figure 6. Gradual completion of each neighborhood, Source Author

Moreover, as due to the limited population of the camp, just one school for each gender was enough, the public facilities such as schools, bus station, and library are centralized, but, as shown in Figure 7, a linear public space including green spaces, small scale retail stores and play grounds is provided along the whole site. This plan can guarantee the equal access of every residents of the camp to such facilities (Figure 12). Additionally, unoccupied spaces is predicted, which will provide more public spaces after the population growth by the passage of time, to prevent any kind of scarcity after the natural growth in the population. 


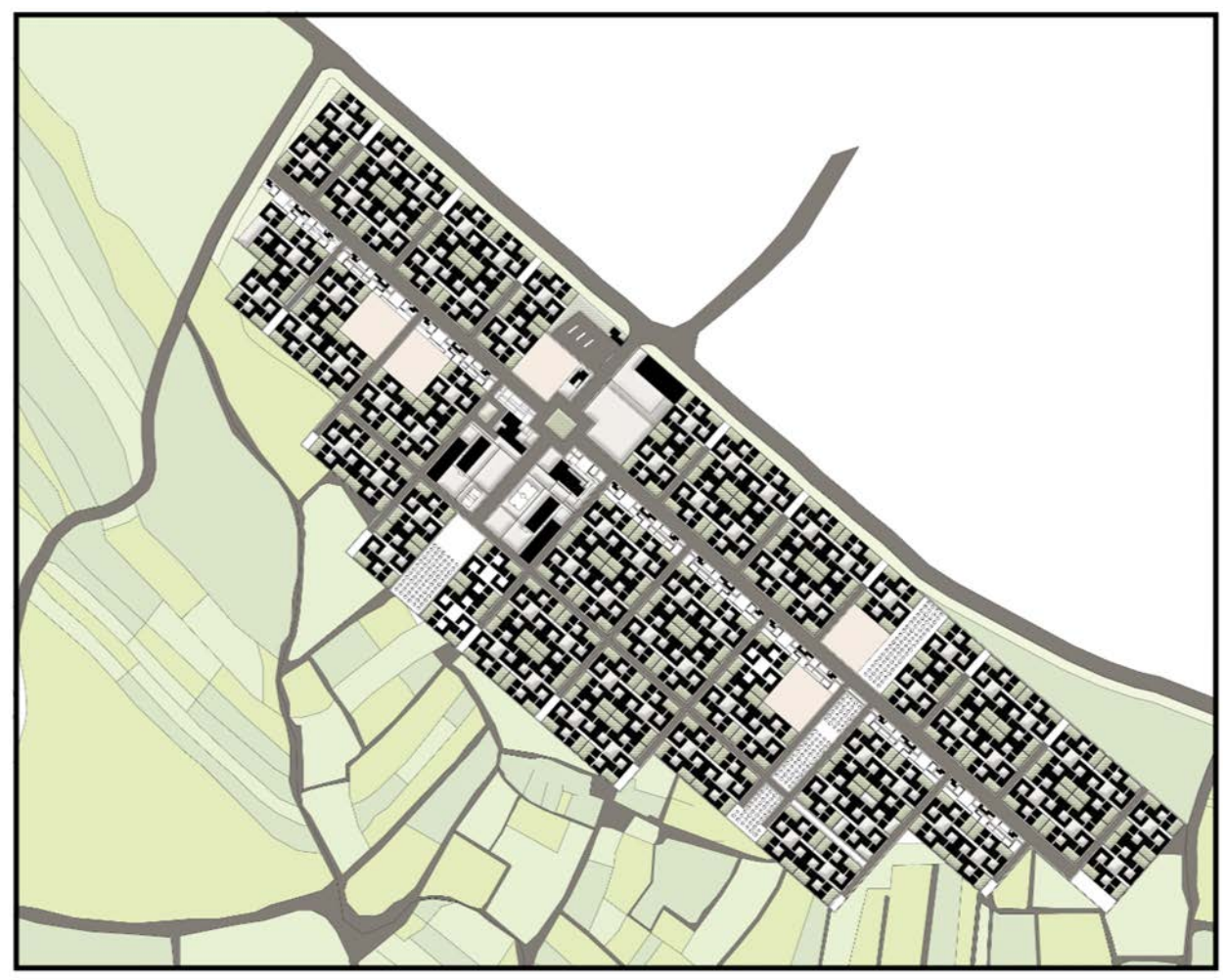

Figure 7. Site Plan
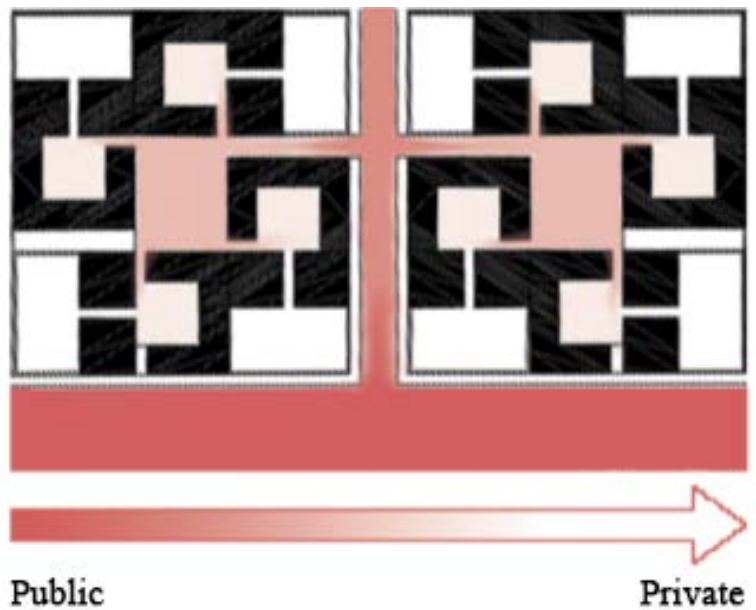

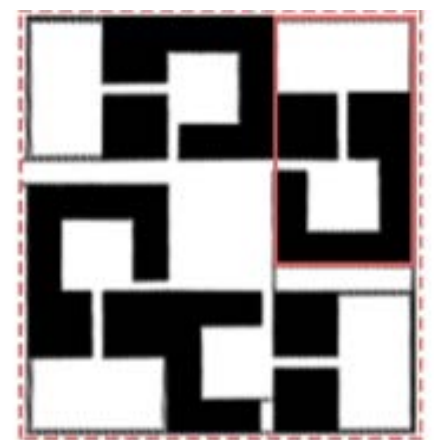

Neighborhood Unit, 4 Families

Community Unit, 16 Families

Figure 8. Neighborhood Unit and Private Spaces, Source Author

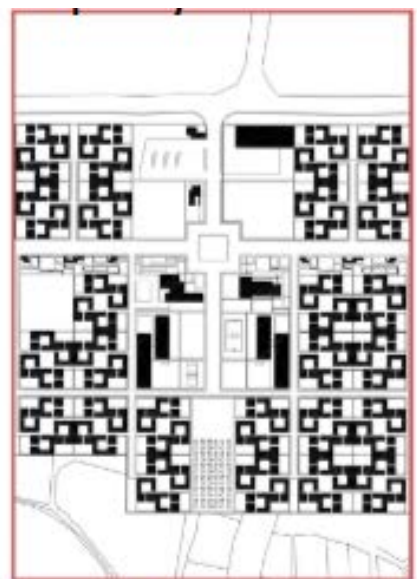

3

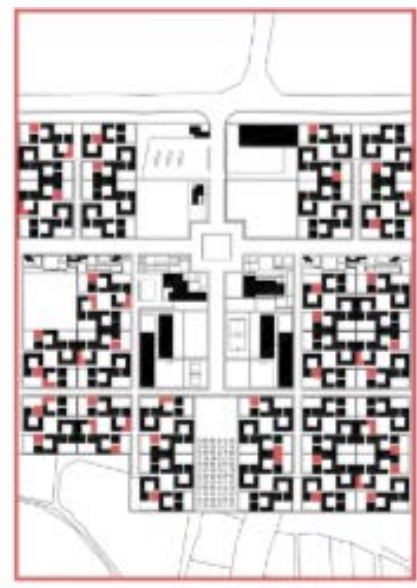

2

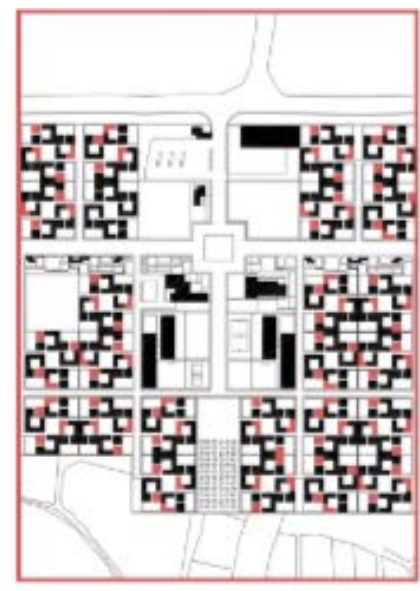

1

Figure 9. The inter-neighborhood expansion plan, Source Author 


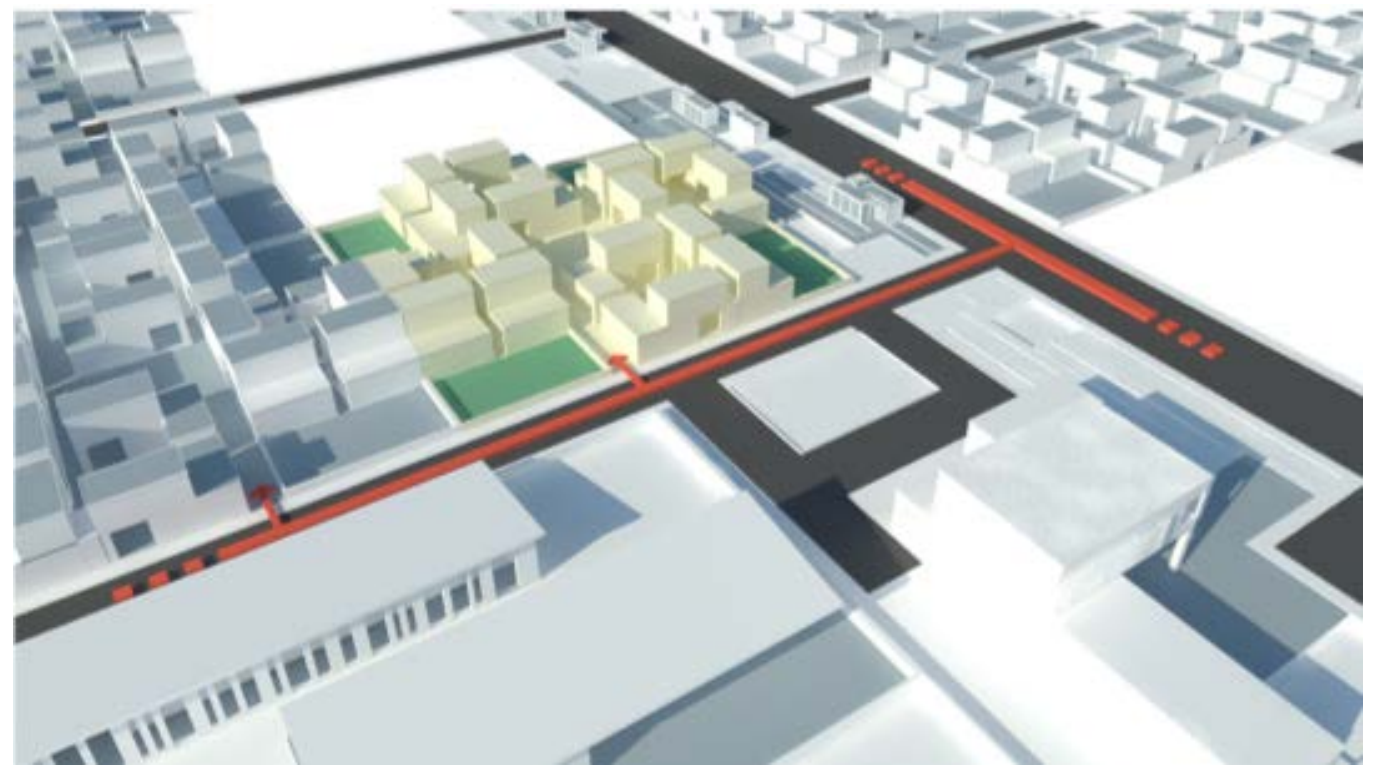

Figure 10. Equal land distribution for planting families' daily needs

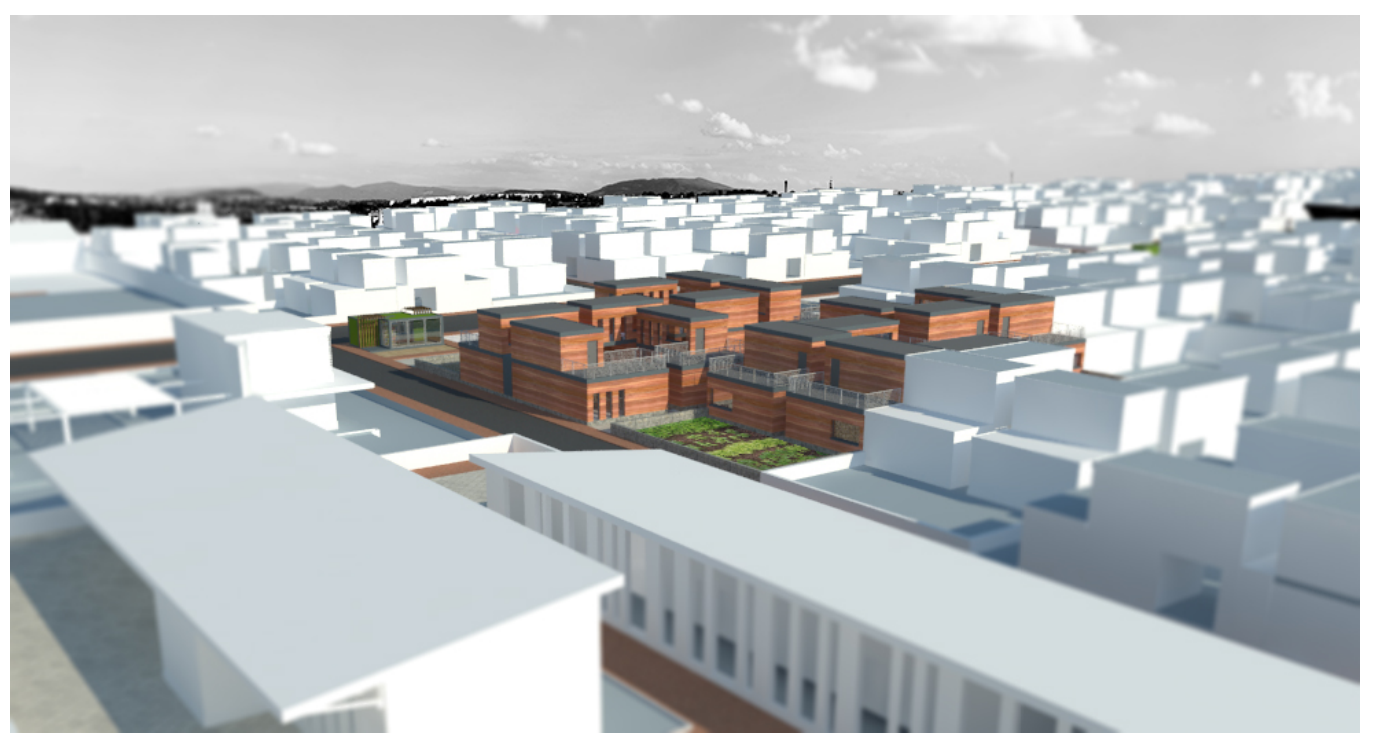

Figure 11. A Community after the redesign in Saveh Camp

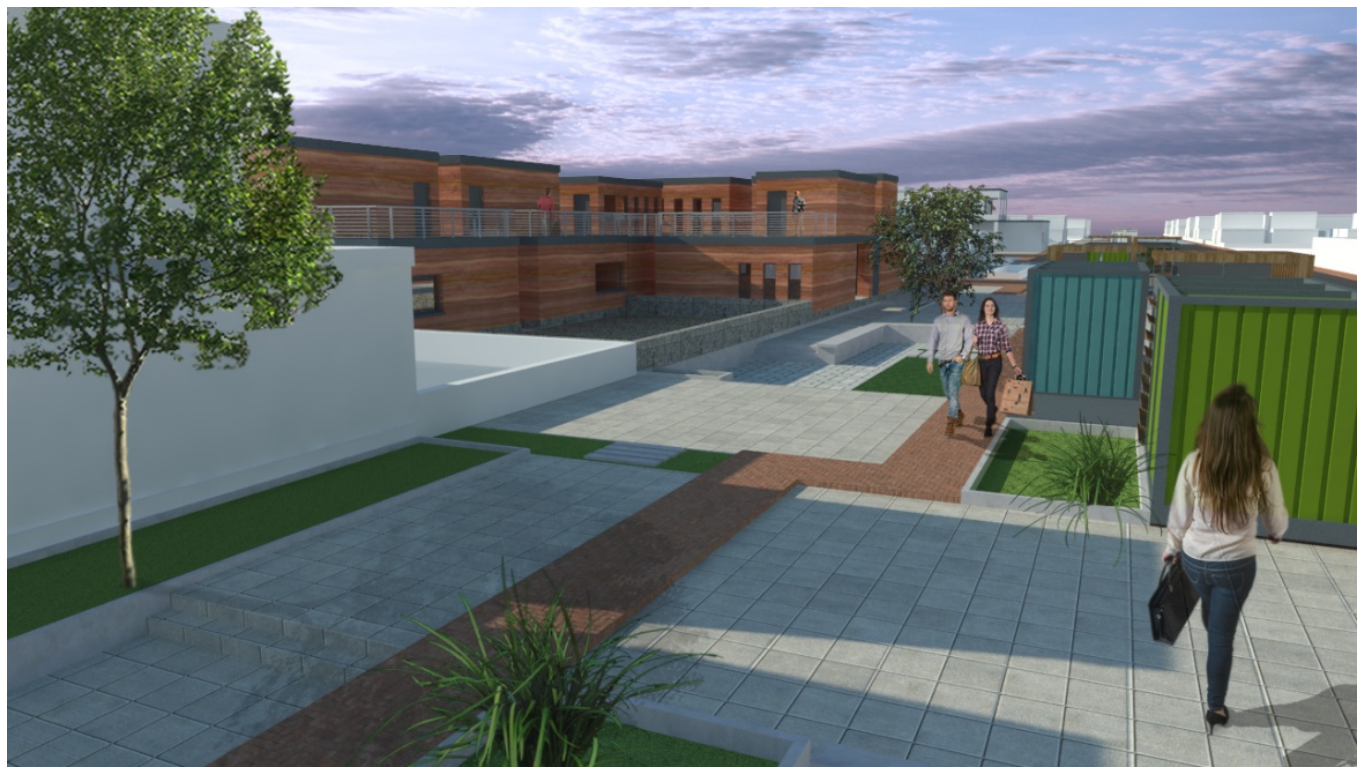

Figure 12. Linear public space along the camp 


\section{Conclusions}

The purpose of this study is to represent refugee camp as a livable city. An important point is that refugees' selfsufficiency, camp's participatory management, and physical design need to be in line with the increase in sense of attachment and the use of refugee workforce for construction. Other findings are the necessity of private space for every family, the possibility of food production by families including plants, attention to environmental issues for reducing the tension among refugees, and attention to all social groups especially vulnerable ones. Although a comprehensive study was expected, other factors of camps and their residents can be taken into account in future studies including the effect of lack of private space on refugee's life, preventive methods for security in camps, application of refugees' potentials in economy, and camp's urban life.

This study focuses on camp as a city through identifying a city's high-quality components and infrastructures. A livability approach can lead to promoted quality of life in all aspects. In this regard, the study aims to help the vulnerable citizens come back to life by local markets, efforts for refugees' self-sufficiency, attention to the pedestrian and urban spaces, creation of green spaces, and the use of green construction methods. As this research is completely in agreement with the UNHCR guidelines, the results of the study can be useful to construct new camps all over the world or even to redesign the current camps which suffer from various issues. Hopefully, the study is able to change the ideas of community members and decision makers towards the camp and its residents so that, regardless of their political, religious, and ideological views, they can have a suitable life in the future.

\section{References}

[1] UNHCR. “UNHCR Mid-Year Trends 2015”.2015. Retrieved January 12, 2016, from http://www.refworld.org/docid/568fbb8f4.html.

[2] UNHCR. "UNHCR Islamic Republic of Iran Global Appeal 2015”. Geneva.2015. Retrieved January 12, 2016, from http://www.unhcr.org/5461e609b.pdf.

[3] Graham, S., Cities, War, and Terrorism, Blackwell Publishing, Malden, MA, USA, 2004.

[4] Grbac, P., "Civitas, polis, and urbs: Reimaging the refugee camp as the city", Oxford: Working Paper series, (96), 2013.

[5] Sanyal, R., "Squatting in camps: Building and insurgency in spaces of refuge”, Urban Studies, 48(5), 877-890, 2011.

[6] Zeus, B., "Exploring Barriers to Higher Education in Protracted Refugee Situations: The Case of Burmese Refugees in Thailand”, Journal of Refugee Studies. 2 (24), 2010.
[7] Wilson, K. B., 'Enhancing Refugees' Own Food Acquisition Strategies", Journal of Refugee Studies, 3, 1992.

[8] Werker, E., "Refugee Camp Economies", Journal of Refugee Studies, 20(3), 461-480, 2007.

[9] Gale, T., "Refugee Camps", International Encyclopedia of the Social Sciences, 2008, Retrieved January 12, 2016, from: http://www.encyclopedia.com/doc/1G2-3045302214.html.

[10] Rashidi, Diba, Refugee Camp Design, Reimaging Refugee camp as a livable city. A Thesis Submitted to Graduate Studies Office in Partial Fulfillment of the Requirements for the Degree of Master of Architecture, University of Art, not published, 2017.

[11] Faragimolai, A., Azimi, A., and Ziari, K., "Analysis of dimensions of quality of life in urban area of Iran", Urban research and planning. (2), 1-16, 2010.

[12] Epley, D. R., \& Menon, M., "A Method of Assembling Crosssectional Indicators into a Community Quality of Life". Social Indicators Research, 88(2), 281-296, 2008.

[13] Khorasani, M., Rezvani, M., Matielenrudi, S., \& Rafiyan, M. "Measuring and Evaluating the Resilience of Urban Villages (Case Study: Varamin County)”, Rural Studies, 79-104, 2012.

[14] Bandar Abad, A. And Ahmadinejad, Farah, "Evaluation of Quality of Life Indicators with Emphasis on Principles of Urban Life in Tehran 22nd District”, Urban research and planning (16), 55-74, 2014.

[15] Herz, M., "Refugee camps or ideal cities in dust and dirt", Urban Transformation, 276-289, 2008.

[16] Cuny, F. C., 'Refugee camps and camp planning: the state of the art”. Disasters, 1(2), 125-143, 1977.

[17] Davis, I., "Disaster Housing: A case Study of Managua", Archirecrural Design. (1), 1975.

[18] Yeager, D. S., OXFAM Operations: Nicaragua, INTERTECT, Dallas, 1973.

[19] Breithaupt, M., Towards Liveable Cities-International Experiences. The Future of Mobility Options for Sustainable Transport in a Low Carbon Society, 2010.

[20] Appleyard, D., Gerson, M. S., \& Lintell, M., Livable streets, protected neighborhoods, University of California Press, 1981.

[21] Lennard, Suzanne H. Crowhurst, and Henry L. Lennard. Livable cities observed: a source book of images and ideas for city officials, community leaders, architects, planners and all other committed to making their cities livable. Gondolier Press, 1995.

[22] Lennard, S. H. C., Lennard, H. L., \& Bert, P., Livable Cities: People and Places: Social and Design Principles for the Future of the City. Center for Urban Well-Being, 1987.

[23] Bandar Abad, A., Livable city from foundations to foundations. Azarakhsh Publishing House Tehran, 2011.

[24] McNulty, R.H., Penne, R.L. and Jacobson, D.R., Partners for Livable Places, The Return of the Livable City: Learning from America's Best, 1986.

[25] Evans, P. B. (Ed.), Livable cities?: Urban struggles for livelihood and sustainability. Univ of California Press, 2002.

[26] Buchwald, E. (Ed.), Toward the livable city. Milkweed Editions, 2003

[27] Elliott, D. L., A better way to zone: ten principles to create more livable cities. Island Press, 2012.

[28] Directorate General of Heritage, Handicrafts and Tourism of Markazi Province “Attractive attractions of Saveh tourism”, 2016, Retrieved December 24, 2016, from http://markazitourist.ir

[29] Pouya Naghsh-e-Bana va Shahr Consulting Engineers, Comprehensive Plan of Saveh City, 2009.

[30] Rashidi, Diba, interview with Lak, Reza.Ministry of Foreign Affairs, (2016, September 15).

[31] Rashidi, Diba, Personal interview with Ghavipanjeh, Ministry of Foreign Affairs, Tehran, (2016, September 17). 